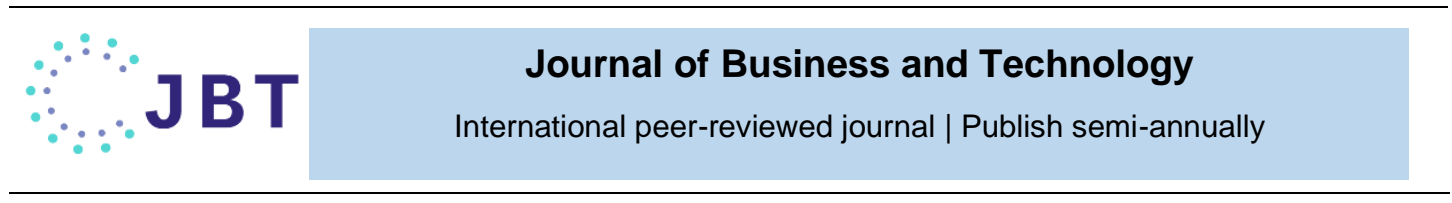

\title{
Behavioral biases and the rationality in stock market investments; evidence from Sri Lanka
}

\author{
Lasantha, S.A.R. ${ }^{1 *}$ and Kumara, W.M.S.W. ${ }^{2}$ \\ 12 Department of Commerce and Financial Management, University of Kelaniya, Sri Lanka. \\ * Corresponding Author: ruwansamarakoon@kln.ac.lk
}

\begin{abstract}
Prospect theory and its evolution, the behavioural finance, suggests that investment decisions could deviate from rationality. This study aims to investigate behavioural biases that influence the investment decisions of stock market investors in Sri Lanka. We have collected the primary data from 250 active investors of the Colombo Stock Exchange. We have used the Structural Equation Modelling technique to test our hypotheses. We find that overconfidence bias and herding bias significantly influence the investment decisions of stock market investors in Sri Lanka. Moreover, familiarity bias, availability bias, confirmation bias, and disposition bias are found to be significant at $10 \%$. We find no evidence to support the influence of representative bias and loss aversion bias. Our study has important implications for investors and regulators. Investors in the stock market should be aware of the possible behavioural biases that may hinder their investment decisions. Further, the regulators should closely monitor the stock market movements to minimize market manipulations initiated by a few who capitalize on the investment biases such as herding and overconfidence for their personal advantage.
\end{abstract}

Keywords: Availability bias, Behavioural biases, Confirmation bias, Disposition, Familiarity, Herding, Investment, Loss-aversion, Overconfidence, Rationality, Representative bias, Stock market, Sri Lanka.

\section{INTRODUCTION}

Investment decision making has been explored under different contexts but mainly with the rational paradigm. Attention to the deviations from rationality is gaining importance among researchers with the introduction of prospect theory (Kahneman and Tversky ,1979). Prospect theory suggests that behavioural biases play a crucial role in decision making; thus, investment decisions are not always rational. Stock markets are no exception that anomalies \& bubbles attributable to behavioural biases are commonly seen, such as the January effect, Friday effect, housing bubble, dot com bubble.(Levis, 1989; Lux, 1995). The failure of traditional finance to explain these anomalies and bubbles has led to the development of behavioural finance which is relatively new both in theory and its applications(Kapoor \& Prosad, 2017). The key motivation of this study is to identify the impact of behvioural biases on investment decision making among stock investors in a developing country context.

Investors' behavioral biases include overconfidence bias, representative bias, herding bias, availability bias, loss aversion bias, disposition bias, familiarity bias, and confirmation bias(Kumar \& Goyal, 2015; Zahera \& Bansal, 2018). The influence of these biases on investment decision making is inconclusive and needs further investigation (Zahera \& Bansal, 2018). Furthermore, Kumar \& Goyal (2015) reveals that limited research is available in developing countries, less research is carried out using primary data, and less focus is on individual investors. We find a dearth of research on behavioural biases in the Sri

1|P a g e 
Lankan context, a developing economy. Among the few research on the behavioral biases of stock market investors in the Sri Lankan context, Kawshala et al. (2020) focused on herding bias, while Gunathilaka \& Fernando (2021) examined four biases; overconfidence, representative bias, disposition effect $\&$ herding bias. In this paper, we examine the influence of eight behavioral biases, including the four examined by previous researchers plus availability bias, loss aversion bias, familiarity bias, and confirmation bias.

We use the data collected from 250 active investors in the Colombo Stock Exchange to examine the influence of behavioral biases on investment decision making. We find evidence for the significant influence of overconfidence bias and herding bias on investment decision making among stock market investors in Sri Lanka. Overconfidence and herding are significant at a 5\% level. Moreover, familiarity bias, availability bias, confirmation bias, and disposition bias are found to be significant at a $10 \%$ significance level. However, we do not find evidence for the influence of representative bias, loss aversion bias, disposition bias, familiarity bias, and confirmation bias.

The study contributes to the empirical literature by examining the existence of a comprehensive list of biases in a developing country context, Sri Lanka, where the previous studies have focused on a few biases. Kumar \& Goyal (2015) reveals that a dearth of research exists in developing countries, and there is less research with primary data focusing on individual investors. Accordingly, our study contributes to the literature by investigating individual investors' behavioral biases using primary data instead of aggregated secondary data. Further, we have employed the Structural Equation Modelling approach for analysis instead of the traditional regression approach.

Our research has important implications for individual investors in the stock market, policy developers, and regulators. The next section reviews the literature on the topic and builds the hypotheses. This is followed by the methodology section that provides details on variables, measurements, reliability, and method of analysis. The fourth section provides the results of our study. Finally, the fifth section outlines the conclusion.

\section{LITERATURE REVIEW \& HYPOTHESES DEVELOPMENT}

Investment decision making is explained using two paradigms; rationality and deviations from rationality, where the first is connected with classical or traditional finance, and the latter is explored in behavioral finance(Chaudhary, 2013). The number of theories supports the traditional paradigm of rationality; expected utility theory by Bernoulli in 1738, portfolio theory by Markowitz in 1952, the life cycle hypotheses introduced by Modigliani and Brumberg in 1954, the permanent income hypothesis introduced by Friedman in 1957, and efficient market hypothesis introduced by Fama in 1970 (Kapoor \& Prosad, 2017). However, these theories failed to explain the stock market bubbles, crashes, and other anomalies that occurred from time to time(Lux, 1995). Evidence against rational behaviour led to the development of the prospect theory that attempts to explain the deviation from rationality (Kahneman \& Tversky, 1979), the foundation theory for behavioral finance concepts. Accordingly, the prospect theory suggests that decision making of individuals is subject to human biases. However, traditional finance theories with rationality assumptions fail to consider human biases in decision making.

Investment decisions of stock market investors are influenced by several behavioral biases that include overconfidence bias, representative bias, herding bias, availability bias, loss aversion bias, disposition bias, familiarity bias, and confirmation bias (Kumar \& Goyal, 2015; Zahera \& Bansal, 2018).

Overconfident investors are highly optimistic about their trading outcome and believe that they have sufficient information to make investment decisions(Zahera \& Bansal, 2018). Overconfident investors trade too much 
(Odean, 1999) and men are more overconfident than women(Barber \& Odean, 2001). Most of the evidence on overconfidence bias is concentrated in developed countries like the USA (Kumar \& Goyal, 2015). Overconfidence bias is found to influence investment decision making in some emerging countries like Pakistan (Rehan \& Umer, 2017), India (Mushinada \& Veluri, 2019; Prosad et al., 2017), and Jordan (Alrabadi et al., 2018). It is likely that Sri Lanka being an emerging economy, overconfidence bias influences investment decision making of stock market investors at the Colombo Stock Exchange. Accordingly, the first hypothesis of the study is presented below.

$H_{I}$ : Overconfidence bias significantly influences investment decisions of stock market investors in Sri Lanka

Familiarity bias refers to the preference of investors towards the investments in the stocks that they are familiar with. Familiarity bias could lead to low diversification (Foad, 2011). Further, he suggests that familiarity bias could be observed in the local stock market and international setting. Investors could display a bias towards local stocks that they are more familiar with. Portfolios with a mix of international stock \& domestic stock could have more weightage towards the local stock due to the familiarity bias. Familiarity bias is found to have a significant influence on investment decision making in the South African Stock market (De Vries et al., 2017). Moreover, familiarity bias is identified to be a significant influencer among the investors in Jordan (Alrabadi et al., 2018). It is likely that Investors in the Sri Lankan stock market also have a bias towards familiar stocks thus, the next hypothesis is proposed below.

$\mathrm{H}_{2}$ : Familiarity bias significantly influences investment decisions of stock market investors in Sri Lanka

Representative bias causes an individual to assess a particular event or object in correspondence with a similar object/event that they came across earlier. The concept was first introduced by Kahneman and Tversky in 1974
(Zahera \& Bansal, 2018). The bias causes the investors to label an investment as good or bad based on the current performance of the investment and judge other investments similar to the labeled categories. This is found to influence in emerging countries such as Jordan (Alrabadi et al., 2018) and Pakistan (Rehan \& Umer, 2017). It is highly likely that the decisions of stock market investors of Sri Lanka are affected by the representative bias.

$\mathrm{H}_{3}$ : Representative bias significantly influences investment decisions of stock market investors in Sri Lanka

Availability bias refers to the tendency that the decision maker considers only the information available for him rather than all relevant information; thus, they overemphasize the information at hand(Kliger \& Kudryavtsev, 2010). They find evidence to support the existence of the availability bias in the New York Stock Exchange. However, availability bias was found to have no significant influence on the investment decision making of investors at the Pakistan Stock Exchange (Rehan \& Umer, 2017). On the contrary, the evidence in Amman Stock Exchange in Jordan shows a significant positive influence of availability bias on decision making (Alrabadi et al., 2018). Despite inconclusive results, the possibility of existing the availability bias in the stock market in Sri Lanka cannot be ruled out; thus, the fourth hypothesis is proposed below.

$\mathrm{H}_{4}$ : Availability bias significantly influences investment decisions of stock market investors in Sri Lanka

Confirmation bias refers to the individual behaviour of seeking evidence to confirm existing beliefs or expectations (Nickerson, 1998). Investors subconsciously seek information to confirm their beliefs while avoiding any conflicting information that is contrary to the belief (Szyszka, 2011). Evidence from the stock market in Jordan suggests there is no significant impact from the confirmation bias on investment decision making (Alrabadi et al., 2018). Moreover, confirmation bias was not significant in the 
Nigerian stock market (Babajide \& Adetiloye, 2012). However, evidence for the presence of confirmation bias is found in the stock market of Kenya (Onsomu et al., 2017). Though inconclusive empirical findings are observed, the possibility of confirmation bias among stock market investors in Sri Lanka cannot be disregarded. Thus, the current study proposes the hypothesis below.

$\mathrm{H}_{5}$ : Confirmation bias significantly influences investment decisions of stock market investors in Sri Lanka

Disposition bias is identified as the tendency to hold losing investments too long and sell winning investments too soon (Shefrin \& Statman, 1985). Odean (1998) finds evidence for disposition effect in a developed country context, the USA. Disposition bias was found to influence stock market investors in India using a study at market level (Prosad et al., 2017). Moreover, a significant influence was also found in Amman Stock Exchange, Jordan (Alrabadi et al., 2018). Disposition bias is likely prevalent among stock market investors in Sri Lanka, similar to other emerging countries.

$H_{6}$ : Disposition bias significantly influences investment decisions of stock market investors in Sri Lanka

Herd behavior is the tendency of individuals to follow the actions of a large group wherein the context of investment decisions; stock market investors may purchase stock based on price momentum without proper evaluation. An investor could imitate the judgments of others instead of making their own decisions thus, herding is identified to be irrational (Kumar \& Goyal, 2015). Herding is found to be more predominant among individual investors than institutional investors (Lee et al., 2004) in Taiwan. Herding bias was also found to have a significant influence on investment decision making in Jordan (Alrabadi et al., 2018). In a market-level study, herd behaviour is identified in the national stock exchange in India as well (Mandal, 2011). Given the evidence for herding bias in developed markets such as Taiwan and developing countries such as Jordan and India, it is likely that stock market investors in Sri Lanka showcase herding bias in their investment decisions.

$H_{7}$ : Herding bias significantly influences investment decisions of stock market investors in Sri Lanka

Investors are more sensitive to losses compared to gains thus, they are keener on avoiding losses rather than acquiring gains (Kahneman \& Tversky, 1979). Loss aversion leads to decision making that deviates from rationality (Kahneman et al., 1991). Loss aversion is found to be positively correlated with the investment decisions among Pakistan stock market investors (Zat \& Khan, 2017). However, it does not have a significant influence in Jordan(Alrabadi et al., 2018). Despite the inconclusive empirical findings in different countries, the theoretical background forces to believe the possible impact of loss aversion bias towards decision making of the investors in Sri Lanka. Thus, the eighth hypothesis is proposed below.

$H_{8}:$ Loss aversion bias significantly influences investment decisions of stock market investors in Sri Lanka

This section covers theoretical explanations and empirical findings on different behavioral biases that could influence investment decision making. The following section provides an overview of the research methodology adopted in the study.

\section{RESEARCH METHODS}

The study has used quantitative methodology as the researchers believe that variables of interest can be measured using standard questions. The population of the study includes all active investors in the Colombo Stock Exchange (CSE) in Sri Lanka. We were compelled to use the snowball sampling approach as the CSE did not provide access to the registered investors' database. Similar approaches have been used by previous researchers in the Sri Lankan context (Gunathilaka \& Fernando, 2021). Primary data is collected using standard questionnaires. We could reach a final sample of 250 investors 
with our approach.

\section{Variables, measurement \& validity}

We have used standard questions used by previous researchers to measure the variables of the study(Alrabadi et al., 2018). These questions are of lickert type with a scale from 1-5. We used Cronbach's alpha to measure the reliability of measurements. Moreover, the validity is tested using a confirmatory factor analysis under the Structural Equation Modelling (SEM) approach. The initial measurement model is provided in figure 1.

Independent variables of the study include eight biases: overconfidence, familiarity, representative, availability, confirmation, disposition, herding, and loss aversion. For brevity, the body of the paper includes measurements, validity, and reliability details of the dependent variable and one independent variable: the overconfidence bias only. Details of the rest of the variables are provided in the annexure 1 .

Overconfidence bias is measured using seven questions and their factor loadings are given in Table 1. Most of the measurements exceed the factor loadings above the rule of thumb of 0.5 except for one item; thus, the measurements used are valid. Reliability is measured using Cronbach's Alpha, and it exceeds the threshold of 0.7. Some of the measurements of other variables record lower factor loadings; thus, they were removed in the structural model. A few measurements showed less reliability in the Sri Lankan context; thus, caution is warranted in interpretation.

Investment performance is used as a proxy for investment decision making as it is the realized outcome of the decision making in line with previous researchers(Alrabadi et al., 2018). This is measured using three statements as provided in Table 2. All three statements have factor loadings above 0.5 , indicating they are valid instruments. Furthermore, Cronbach's Alpha exceeds 0.7 threshold.

We have improved the initial measurement model using covariates and removing items with low factor loading. The final measurement shows a relative chi-square value of 2.092, which is less than the cut-off value of 3 (Hooper et al., 2008). Furthermore, Root Mean Square Error of Approximation (RMSEA) stood at 0.066, which is less than threshold value of 0.07 (Hooper et al., 2008).

\section{Table 1: Overconfidence bias}

\begin{tabular}{|c|c|c|c|}
\hline \# & Measurement & $\begin{array}{l}\text { Factor } \\
\text { loading }\end{array}$ & $\begin{array}{l}\text { Cronbach's } \\
\text { Alpha }\end{array}$ \\
\hline OB1 & I am an experienced investor & 0.550 & \multirow{7}{*}{0.751} \\
\hline OB2 & $\begin{array}{l}\text { I feel that on average my investment performs better than } \\
\text { the stock market }\end{array}$ & 0.558 & \\
\hline OB3 & $\begin{array}{l}\text { I feel that I can, on average, predict future share prices } \\
\text { better than others }\end{array}$ & 0.622 & \\
\hline OB4 & $\begin{array}{l}\text { When I purchase a winning investment, I feel that my } \\
\text { actions and knowledge affect the result }\end{array}$ & 0.667 & \\
\hline OB5 & $\begin{array}{l}\text { My past profitable investments were mainly due to my } \\
\text { specific investment skill }\end{array}$ & 0.649 & \\
\hline OB6 & $\begin{array}{l}\text { I believe my skill and knowledge of stock market can help } \\
\text { me to outperform the market }\end{array}$ & 0.673 & \\
\hline OB7 & $\begin{array}{l}\text { I believe sharing others opinions would decrease my } \\
\text { success opportunity }\end{array}$ & 0.235 & \\
\hline
\end{tabular}


Table 2: Investment performance

\begin{tabular}{llcc}
\hline$\#$ & Measurement & $\begin{array}{c}\text { Factor } \\
\text { loading }\end{array}$ & $\begin{array}{c}\text { Cronbach's } \\
\text { Alpha }\end{array}$ \\
\cline { 1 - 2 } IP1 & $\begin{array}{l}\text { The return rate of your recent stock investment meets } \\
\text { your expectation }\end{array}$ & 0.723 & \multirow{2}{*}{0.756} \\
\cline { 1 - 2 } IP2 & $\begin{array}{l}\text { Your rate of return is equal to or higher than the average } \\
\text { return rate of the market }\end{array}$ & 0.776 & \\
\cline { 1 - 2 } IP3 & $\begin{array}{l}\text { You feel satisfied with your investment decisions in the } \\
\text { last year (including selling, buying, choosing stocks and } \\
\text { deciding the stock volumes ) }\end{array}$ & 0.643 & \\
\hline
\end{tabular}

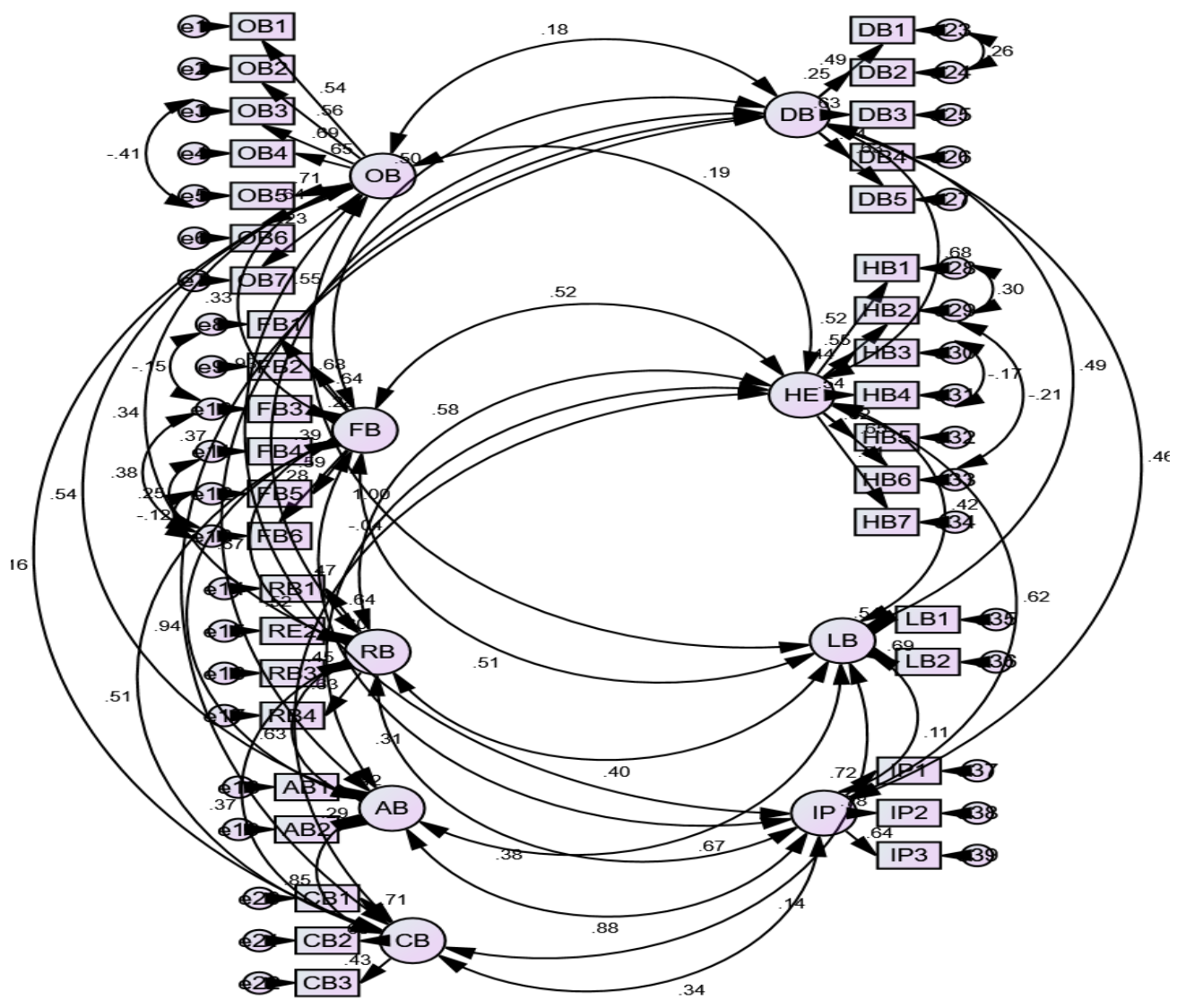

Figure 1: Initial measurement model 


\section{Model specification}

We test our hypotheses $\left(\mathrm{H}_{1}-\mathrm{H}_{8}\right)$ using the following model specification under the Structural Equation Modelling approach.

Each variable is measured as discussed in the preceding section. The usual assumptions such as normality, heteroscedasticity, etc. tested prior to using the structural model.

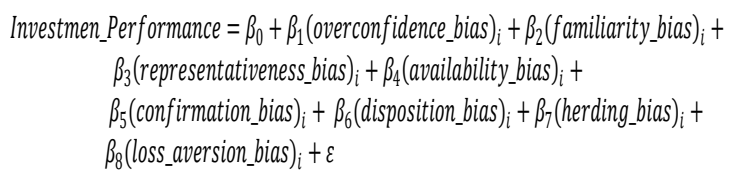

\section{FINDINGS \& DISCUSSION}

Descriptive statistics of the study are initially reported. This is followed by hypothesis testing and a discussion.

\section{Descriptive statistics}

Demographic characteristics of the investors are presented in Table 3. Our total sample includes 250 investors, out of whom $56 \%$ are male. It could be observed that $36 \%$ of the respondents are in the age category of 20-25 and another $31 \%$ belong to $26-30$. Rest of the respondents are over the age of 30 . About $67 \%$ of the respondents have completed a degree or postgraduate course. The balance respondents have completed a diploma or advanced level. Most of the investors are private-sector employees, accounting for $52 \%$, while around $16 \%$ are government employees.

Around $69 \%$ of investors of the stock market earn below Rs. 1,200,000 annual income. It is observed that about $69 \%$ of investors have invested less than Rs. 50,000 in the stock market, which is closer to $5 \%$ of annual income. About $76 \%$ of investors have been in the stock market for less than three years. Further, a 5\% of investors have been trading in the stock market for over seven years.

\section{Regression results \& hypothesis testing}

We have performed Structural Equation Modelling to test our hypotheses. Assumptions such as normality, heteroscedasticity, multicollinearity, and linearity have been tested before performing the structural model. All assumptions have been satisfactorily met, and some of the assumptions are reported in the forthcoming paragraphs.

Skewness and kurtosis values have been used to check whether the data is approximately normally distributed and reported in Table 4. According to Garson (2012), if both skewness and kurtosis values lie in the range +2.00 to 2.00 , data are suggested to follow a normal distribution. Except for the marginal deviation of overconfidence bias, rest of the variables follow a normal distribution. More importantly, the requirement of the dependent variable to follow a normal distribution is met.

We have scrutinized whether our model suffers from the heteroscedasticity issue using scatterplot for regression standardized residual vs. regression standardized predicted value. We find an equal scatter, and no pattern is observed. Accordingly, we have concluded that our model does not suffer from heteroscedasticity. Linearity was also observed using a scatter plot for each independent variable with the dependent variable. We observed a linear relationship for all our independent variables. Multicollinearity assumption was tested using Variance Inflation Factor (VIF) and Tolerance values as reported in Table 4. VIF should be greater than 0.1 , and tolerance needs to be less than 10 as per rule of thumb to avoid multicollinearity. These thresholds have been satisfactorily met.

We have tested our hypothesis using the structural model depicted in figure 2. Results are provided in Table 5. Accordingly, overconfidence bias \& herding bias are found to significantly influence investment performance, the result of their ultimate investment decisions. Familiarity bias, availability bias, confirmation bias, and disposition bias are significant influencers but at a significant level of $10 \%$. Representative bias and loss aversion bias has no influence on the investment decisions of investors. 
Table 3: Demographic characteristics of investors

\begin{tabular}{|c|c|c|}
\hline Demographic variable & Frequency & Percentage \\
\hline \multicolumn{3}{|l|}{ Gender } \\
\hline Male & 141 & $56.40 \%$ \\
\hline Female & 109 & $43.60 \%$ \\
\hline \multicolumn{3}{|l|}{ Age range } \\
\hline $20-25$ & 90 & $36.00 \%$ \\
\hline $26-30$ & 77 & $30.80 \%$ \\
\hline $31-35$ & 42 & $16.80 \%$ \\
\hline $36-40$ & 24 & $9.60 \%$ \\
\hline $41-45$ & 13 & $5.20 \%$ \\
\hline $46-50$ & 2 & $0.80 \%$ \\
\hline $56-60$ & 2 & $0.80 \%$ \\
\hline \multicolumn{3}{|l|}{ Education level } \\
\hline Up to advanced level & 39 & $15.60 \%$ \\
\hline Diploma in specific field & 44 & $17.60 \%$ \\
\hline Graduate & 143 & $57.20 \%$ \\
\hline Postgraduate & 24 & $9.60 \%$ \\
\hline \multicolumn{3}{|l|}{ Occupation } \\
\hline Sole proprietor /partner & 25 & $10.00 \%$ \\
\hline Employee in private organization & 129 & $51.60 \%$ \\
\hline Government employee & 39 & $15.60 \%$ \\
\hline Retired & 1 & $0.40 \%$ \\
\hline Other & 56 & $22.40 \%$ \\
\hline \multicolumn{3}{|l|}{ Annual income } \\
\hline $0-600,000$ & 134 & $53.60 \%$ \\
\hline $600,001-1,200,000$ & 64 & $25.60 \%$ \\
\hline $1,200,001-1,800,000$ & 31 & $12.40 \%$ \\
\hline $1,800,001-2,400,000$ & 8 & $3.20 \%$ \\
\hline $2,400,001-3,000,000$ & 6 & $2.40 \%$ \\
\hline $3,000,001$ Or more & 7 & $2.80 \%$ \\
\hline \multicolumn{3}{|l|}{ Invested amount } \\
\hline 10,000 Or less & 106 & $42.40 \%$ \\
\hline $10,001-50,000$ & 67 & $26.80 \%$ \\
\hline $50,001-100,000$ & 25 & $10.00 \%$ \\
\hline $100,001-200,000$ & 16 & $6.40 \%$ \\
\hline $200,001-300,000$ & 13 & $5.20 \%$ \\
\hline $300,000-400,000$ & 10 & $4.00 \%$ \\
\hline $400,001-500,000$ & 2 & $0.80 \%$ \\
\hline 500,001 Or more & 11 & $4.40 \%$ \\
\hline \multicolumn{3}{|l|}{ Time period of investment } \\
\hline Less than one year & 99 & $39.60 \%$ \\
\hline 1-3 Years & 92 & $36.80 \%$ \\
\hline 3-5 Years & 36 & $14.40 \%$ \\
\hline 5-7 Years & 10 & $4.00 \%$ \\
\hline More than 7 Years & 13 & $5.20 \%$ \\
\hline
\end{tabular}


Table 4: Skewness \& Kurtosis

\begin{tabular}{lrrrr}
\hline Variable & Skewness & \multicolumn{1}{c}{ Kurtosis } & \multicolumn{1}{c}{ VIF } & \multicolumn{1}{c}{ Tolerance } \\
\hline Overconfidence bias & -1.126 & 2.620 & 0.844 & 1.185 \\
\hline Familiarity bias & -.725 & 1.551 & 0.615 & 1.625 \\
\hline Representative bias & -.576 & .743 & 0.688 & 1.453 \\
\hline Availability bias & -.055 & .670 & 0.72 & 1.390 \\
\hline Confirmation bias & -.234 & .670 & 0.742 & 1.348 \\
\hline Disposition bias & -.678 & 1.873 & 0.588 & 1.700 \\
\hline Herding bias & -.569 & 1.505 & 0.579 & 1.726 \\
\hline Loss-aversion bias & -.243 & -.078 & 0.77 & 1.298 \\
\hline Investment performance & -.671 & .244 & N/A & N/A \\
\hline
\end{tabular}

Table 5: Structural model results

\begin{tabular}{lrrrr}
\hline \multicolumn{1}{c}{ Variables } & \multicolumn{1}{c}{ B } & \multicolumn{1}{c}{ St. Error } & \multicolumn{1}{c}{ C.R. } & \multicolumn{1}{c}{ P-value } \\
\hline $\mathrm{H}_{1}$-Overconfidence bias & 0.504 & 0.1 & 5.058 & 0.001 \\
\hline $\mathrm{H}_{2}$-Familiarity bias & -0.118 & 0.062 & -1.904 & 0.057 \\
\hline $\mathrm{H}_{3}$-Representative bias & 0.109 & 0.074 & 1.464 & 0.143 \\
\hline $\mathrm{H}_{4}$-Availability bias & 1.261 & 0.75 & 1.681 & 0.093 \\
\hline $\mathrm{H}_{5}$-Confirmation bias & 0.241 & 0.132 & 1.826 & 0.068 \\
\hline $\mathrm{H}_{6}$-Disposition bias & 0.201 & 0.123 & 1.64 & 0.101 \\
\hline $\mathrm{H}_{7}$-Herding bias & 0.752 & 0.162 & 4.637 & 0.001 \\
\hline $\mathrm{H}_{8}$-Loss-aversion bias & -0.17 & 0.112 & -1.518 & 0.129 \\
\hline
\end{tabular}

Dependent: Investment performance

Based on the structural model results, H1 \& H7 hypotheses are accepted at the significance level of 5\%. Accordingly, overconfidence bias and herding bias significantly influence investors' decisions of the stock market in Sri Lanka. Furthermore, H2, H4, H5 \& H6 hypotheses could also be accepted if 10 significance level is employed. This means that the investment decisions of investors in the stock market in Sri Lanka are influenced by familiarity bias, availability bias, confirmation bias and disposition bias. The two hypotheses, H3 \& H6, are rejected, suggesting no influence from the representative and loss-aversion biases.

Similar to the finding that Sri Lankan stock market investors are overconfident, other emerging countries like Pakistan (Rehan \& Umer, 2017), India (Mushinada \& Veluri, 2019; Prosad et al., 2017) and Jordan (Alrabadi et al., 2018) shows the same result. Herding bias is also observed in other emerging countries such as India (Mandal, 2011) and Jordan (Alrabadi et al., 2018), similar to Sri Lanka. Our findings related to representative bias contradict Jordan's results (Alrabadi et al., 2018) but are similar to the investors in Pakistan Stock Exchange (Rehan \& Umer, 2017). Our study finds no significant influence of loss aversion towards investment decision making. A similar result is found in Jordan (Alrabadi et al., 2018); however, our results contradict the finding in Pakistan (Zat \& Khan, 2017).

\section{CONCLUSION, LIMITATIONS AND FUTURE RESEARCH DIRECTIONS}

Behavioral finance, an emerging discipline, suggests that investors can deviate from rationality when making investment decisions. Theory and empirical research provide the 


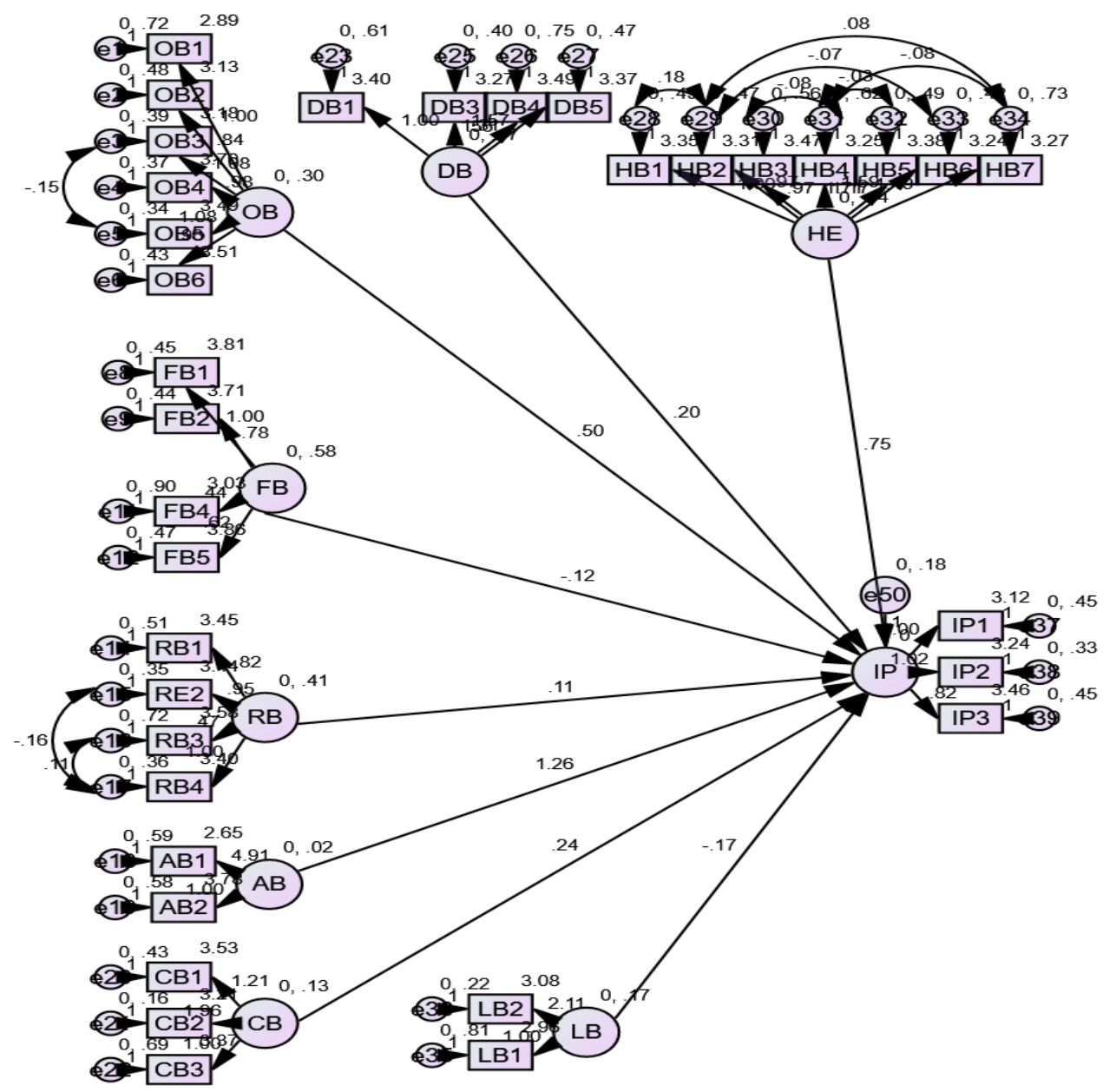

\section{Figure 2: Structural Model}

standpoint that stock market investors are affected by several biases such as overconfidence bias, familiarity bias, representative bias, availability bias, confirmation bias, disposition bias, herding bias, and loss aversion bias. We find evidence for overconfidence bias, familiarity bias, availability bias, confirmation bias, disposition bias, and herding bias among stock market investors in Sri Lanka, which significantly influence their investment decisions.

Limitations of our study include the sample size, which is limited to 250 investors in the stock market. Moreover, we were compelled to use the snowball sampling approach as database access was unavailable from the entity that records investor details. This may hinder the generalizability of the results. However, the researchers generally believe that it is impractical to draw perfect random samples from human subjects due to the limitations such as non-respondence.

Our research has important implications for investors in the stock market as well as policymakers. Stock market investors in Sri Lanka needs to realize the fact that their investment decisions are hindered due to behavioral biases such as overconfidence and herding. This may bring adverse outcomes to their investment. Policymakers and regulators need to initiate investment education programmes to educate investors on 
investment behaviour. Moreover, the regulators of stock market should closely monitor the market movements to minimize stock market manipulations that a few capitalize on these behavioral biases to dry out the funds of the less-knowledgeable retail investors.

Further research is recommended by extending the sample size. Moreover, it may be possible to have a different investment behavior based on the investor's demographic profile, such as gender and education level.

\section{REFERENCES}

Alrabadi, D. W. H., Al-Abdallah, S. Y., \& Aljarayesh, N. I. A. (2018). Behavioral Biases And Investment Performance, Does Gender Matter? :, Evidence From Amman Stock Exchange. Jordan Journal of Economic Sciences, 5(1), 77-92. https://doi.org/10.35516/1250-005-001006

Babajide, A. A., \& Adetiloye, K. A. (2012). Investors' Behavioural Biases and the Security Market: An Empirical Study of the Nigerian Security Market. Accounting and Finance Research, 1(1), 219-229. https://doi.org/10.5430/afr.v1n1p219

Barber, B. M., \& Odean, T. (2001). Boys will be boys: Gender, overconfidence, and common stock investment. Quarterly Journal of Economics, 116(1), 261-292. https://doi.org/10.1162/003355301556400

Chaudhary, A. K. (2013). Impact of behavioral finance in investment decisions and strategies - a fresh approach. International Journal of Management Research and Business Strategy, 2(2), 85-92. https://doi.org/10.1007/s12526-015-03535

De Vries, A., Erasmus, P. D., \& Gerber, C. (2017). The familiar versus the unfamiliar: Familiarity bias amongst individual investors. Acta Commercii, 17(1), 1-10. https://doi.org/10.4102/ac.v17i1.366

Foad, H. (2011). Familiarity Bias. In Behavioral Finance: Investors,
Corporations, and Markets (pp. 277-294). https://doi.org/10.1002/9781118258415.ch 33

Garson, G. (2012). Testing Statistical Assumptions . Statistical Associates Publishing.

Gunathilaka, R. C., \& Fernando, J. M. R. (2021). Do behavioral biases differ among institutional and individual investors? Accounting and Finance, 2(2(92)), 61-73. https://doi.org/10.33146/2307-9878-20212(92)-61-73

Hooper, D., Coughlan, J., \& Mullen, M. R. (2008). Structural equation modelling: Guidelines for determining model fit. Electronic Journal of Business Research Methods, 6(1), 53-60. https://doi.org/10.21427/D79B73

Kahneman, D., Knetsch, J. L., \& Thaler, R. H. (1991). Anomalies: The endowment effect, loss aversion, and status quo bias. The Journal of Economic Perspectives, 5(1), 193-206.

https://doi.org/10.1017/CBO97805118034 75.009

Kahneman, D., \& Tversky, A. (1979). Prospect Theory: An Analysis of Decision under Risk. Econometrica, 47(2), 263-292. https://doi.org/10.2307/1914185

Kapoor, S., \& Prosad, J. M. (2017). Behavioural Finance: A Review. Procedia Computer Science, 122, 50-54. https://doi.org/10.1016/j.procs.2017.11.34 0

Kawshala, B. A. ., Anuradha, P. A. N. S., \& Shamil, M. M. (2020). Socio-Economic, Trading Sophistication and Self-Reflection on Investors' Herding Bias: Evidence From Colombo Stock Exchange. International Journal of Management, Innovation \& Entrepreneurial Research, 6(2), 128-138. https://doi.org/10.18510/ijmier.2020.6212

Kliger, D., \& Kudryavtsev, A. (2010). The Availability Heuristic and Investors' Reaction to Company-Specific Events. Journal of Behavioral Finance, 11(1), 50 
65.

https://doi.org/10.1080/154275610035911 16

Kumar, S., \& Goyal, N. (2015). Behavioural biases in investment decision making - a systematic literature review. Qualitative Research in Financial Markets, 7(1), 88108. https://doi.org/10.1108/QRFM-072014-0022

Lee, Y. T., Liu, Y. J., Roll, R., \& Subrahmanyam, A. (2004). Order imbalances and market efficiency: Evidence from the Taiwan Stock Exchange. Journal of Financial and Quantitative Analysis, 39(2), 327-341. https://doi.org/10.1017/s00221090000030 94

Levis, M. (1989). Stock market anomalies. A re-assessment based on the UK evidence. Journal of Banking and Finance, 13(4-5), 675-696. https://doi.org/10.1016/03784266(89)90037-X

Lux, T. (1995). Herd Behaviour, Bubbles and Crashes. The Economic Journal, 105(431), 881. https://doi.org/10.2307/2235156

Mandal, A. (2011). Empirical Study of Herd Behavior: The National Stock Exchange, India. International Journal of Financial Management, 1(3), 1-11.

Mushinada, V. N. C., \& Veluri, V. S. S. (2019). Elucidating investors rationality and behavioural biases in Indian stock market. Review of Behavioral Finance, 11(2), 201219. https://doi.org/10.1108/RBF-042018-0034

Nickerson, R. S. (1998). Confirmation bias: a ubiquitous phenomenon in many guises. Review of General Psychology, 2(2), 175220.

Odean, T. (1998). Are investors reluctant to realize their losses? The Journal of Finance, $\quad \operatorname{LIII}(5), \quad$ 1775-1798. https://doi.org/10.1017/CBO97805118034 75.022

Odean, T. (1999). Do investor trade too much? American Economic Review, 89(5), 1279-
1298.

Onsomu, Z. N., Kaijage, P. E., Aduda, P. J., \& Iraya, C. (2017). Demograpics and Investors Biases at the Nairobi Securities Exchange,Kenya. Interntional Journal of Arts and Commerce, 6(5), 51-60.

Prosad, J. M., Kapoor, S., Sengupta, J., \& Roychoudhary, S. (2017). Overconfidence and Disposition Effect in Indian Equity Market: An Empirical Evidence. Global Business Review, 19(5), 1303-1321. https://doi.org/10.1177/097215091772666 0

Rehan, R., \& Umer, I. (2017). Behavioural Biases and Investor Decisions. Market Forces, XII(2), 12-20.

Shefrin, H., \& Statman, M. (1985). The Disposition to Sell Winners Too Early and Ride Losers Too Long: Theory and Evidence. The Journal of Finance, 40(3), 777-790. https://doi.org/10.1111/j.15406261.1985.tb05002.x

Szyszka, A. (2011). Confirmation Bias. In Behavioral Finance: Investors, Corporations, and Markets (pp. 351-372). https://doi.org/10.1007/978-1-4419-14286_2086

Zahera, S. A., \& Bansal, R. (2018). Do investors exhibit behavioral biases in investment decision making? A systematic review. Qualitative Research in Financial Markets, 10(2), 210-251. https://doi.org/10.1108/QRFM-04-20170028

Zat, M., \& Khan, U. (2017). Impact Of Availability Bias And Loss Aversion Bias On Investment Decision Making, Moderating Role Of Risk Perception. IMPACT: Journal of Modern Developments in General Management \& Administration, $\quad$ (1), 17-28. www.impactjournals.us. 
Annexure 01 : Validity \& Reliability

\section{Annexure}

\begin{tabular}{|c|c|c|c|}
\hline \# & Measurement & $\begin{array}{l}\text { Factor } \\
\text { loading }\end{array}$ & $\begin{array}{l}\text { Cronbach's } \\
\text { Alpha }\end{array}$ \\
\hline & Overconfidence bias & & \multirow{8}{*}{0.751} \\
\hline OB1 & I am an experienced investor & 0.550 & \\
\hline OB2 & $\begin{array}{l}\text { I feel that on average my investment performs better than } \\
\text { the stock market }\end{array}$ & 0.558 & \\
\hline OB3 & $\begin{array}{l}\text { I feel that I can, on average, predict future share prices } \\
\text { better than others }\end{array}$ & 0.622 & \\
\hline OB4 & $\begin{array}{l}\text { When I purchase a winning investment, I feel that my } \\
\text { actions and knowledge affect the result }\end{array}$ & 0.667 & \\
\hline OB5 & $\begin{array}{l}\text { My past profitable investments were mainly due to my } \\
\text { specific investment skill }\end{array}$ & 0.649 & \\
\hline OB6 & $\begin{array}{l}\text { I believe my skill and knowledge of stock market can help } \\
\text { me to outperform the market }\end{array}$ & 0.673 & \\
\hline \multirow[t]{2}{*}{ OB7 } & $\begin{array}{l}\text { I believe sharing others opinions would decrease my } \\
\text { success opportunity }\end{array}$ & 0.235 & \\
\hline & Familiarity bias & & \\
\hline FB1 & I just look at the company names before investing & 0.635 & \multirow{6}{*}{0.659} \\
\hline FB2 & $\begin{array}{l}\text { I prefer to invest in the well -known companies that have } \\
\text { wider media coverage }\end{array}$ & 0.608 & \\
\hline FB3 & $\begin{array}{l}\text { I prefer to invest in those shares where my father has } \\
\text { invested }\end{array}$ & 0.301 & \\
\hline FB4 & $\begin{array}{l}\text { I prefer to invest locally and not to diversify my portfolio } \\
\text { internationally }\end{array}$ & 0.434 & \\
\hline FB5 & $\begin{array}{l}\text { I prefer to invest in the companies which I know their } \\
\text { history and management. }\end{array}$ & 0.569 & \\
\hline \multirow[t]{2}{*}{ FB6 } & $\begin{array}{l}\text { I am in X industry, so I only invest in companies of this } \\
\text { industry . }\end{array}$ & 0.353 & \\
\hline & Availability bias & & \\
\hline $\mathrm{AB} 1$ & $\begin{array}{l}\text { Before buying a share, I ignore the information in the } \\
\text { market that conflict with my information }\end{array}$ & 0.426 & \multirow{2}{*}{0.213} \\
\hline \multirow[t]{2}{*}{$\mathrm{AB} 2$} & $\begin{array}{l}\text { Before buying a share I appreciate the information in the } \\
\text { market that support my information }\end{array}$ & 0.291 & \\
\hline & Confirmation bias & & \\
\hline CB1 & $\begin{array}{l}\text { I prefer to buy stocks in the days that witness an increase } \\
\text { in the general index of Colombo Stock Exchange }\end{array}$ & 0.718 & \multirow{2}{*}{0.609} \\
\hline CB2 & $\begin{array}{l}\text { I prefer to sell stocks in the days that witness a decrease in } \\
\text { the general index of Colombo Stock Exchange }\end{array}$ & 0.647 & \\
\hline
\end{tabular}




\begin{tabular}{|c|c|c|c|}
\hline \# & Measurement & $\begin{array}{l}\text { Factor } \\
\text { loading }\end{array}$ & $\begin{array}{l}\text { Cronbach's } \\
\text { Alpha }\end{array}$ \\
\hline \multirow[t]{2}{*}{ CB3 } & $\begin{array}{l}\text { prefer to buy local stocks than international stocks because } \\
\text { the information on local stocks is more available }\end{array}$ & 0.433 & \\
\hline & Disposition bias & & \\
\hline DB1 & $\begin{array}{l}\text { I prefer to quickly sell stocks whose prices have recently } \\
\text { increased }\end{array}$ & 0.536 & \multirow{5}{*}{0.575} \\
\hline DB2 & $\begin{array}{l}\text { When the stock prices started to decrease, I don't like to } \\
\text { quickly sell them }\end{array}$ & 0.326 & \\
\hline DB3 & $\begin{array}{l}\text { I tend to sell profitable stocks too early and sell losing } \\
\text { stocks too late and I do not have any quick responses to } \\
\text { good or bad news. }\end{array}$ & 0.620 & \\
\hline DB4 & I am often reluctant to realize losses & 0.344 & \\
\hline \multirow[t]{2}{*}{ DB5 } & $\begin{array}{l}\text { I sell profitable stocks because I am afraid that the stock } \\
\text { price would fall again }\end{array}$ & 0.606 & \\
\hline & Herding bias & & \\
\hline HB1 & $\begin{array}{l}\text { I prefer to buy stocks that witnessed many buying orders } \\
\text { during the trading day }\end{array}$ & 0.585 & \multirow{7}{*}{0.743} \\
\hline HB2 & $\begin{array}{l}\text { I prefer to sell stocks that witnessed many selling orders } \\
\text { during the trading day }\end{array}$ & 0.573 & \\
\hline HB3 & $\begin{array}{l}\text { I follow social blogs/forums before making a stock sell / } \\
\text { purchase }\end{array}$ & 0.424 & \\
\hline HB4 & $\begin{array}{l}\text { I rarely consult others before making a stock purchase or } \\
\text { sell }\end{array}$ & 0.516 & \\
\hline HB5 & $\begin{array}{l}\text { Other investors decision of buying and selling stock } \\
\text { affect my investment decision }\end{array}$ & 0.621 & \\
\hline HB6 & $\begin{array}{l}\text { I usually react quickly to changes in other investors } \\
\text { decision and follow their reaction to stock market }\end{array}$ & 0.616 & \\
\hline \multirow[t]{2}{*}{ HB7 } & $\begin{array}{l}\text { I consult others(family, friend or colleagues ) before } \\
\text { making decision }\end{array}$ & 0.498 & \\
\hline & Loss aversion bias & & \\
\hline LB1 & $\begin{array}{l}\text { If I have savings of R } 100,000 \text {, I would prefer to invest } \\
\text { them in a bank account not in stocks to avoid engaging in } \\
\text { risk. }\end{array}$ & 0.559 & \multirow[t]{2}{*}{0.537} \\
\hline \multirow[t]{2}{*}{ LB2 } & $\begin{array}{l}\text { I prefer low risk investments over risky investments even } \\
\text { if their returns is low }\end{array}$ & 0.656 & \\
\hline & Investment performance & & \\
\hline IP1 & $\begin{array}{l}\text { The return rate of your recent stock investment meets your } \\
\text { expectation }\end{array}$ & 0.723 & \multirow{3}{*}{0.756} \\
\hline IP2 & $\begin{array}{l}\text { Your rate of return is equal to or higher than the average } \\
\text { return rate of the market }\end{array}$ & 0.776 & \\
\hline IP3 & $\begin{array}{l}\text { You feel satisfied with your investment decisions in the } \\
\text { last year (including selling, buying, choosing stocks and } \\
\text { deciding the stock volumes ) }\end{array}$ & 0.643 & \\
\hline
\end{tabular}

